\title{
PESANTREN LANSIA: TELAAH PADA PENDIDIKAN SPIRITUAL SANTRI LANSIA DI PONDOK SEPUH PAYAMAN MAGELANG
}

\author{
Dwi Agustina \\ Departemen Sosiologi, Universitas Gadjah Mada \\ dwiagustina538@gmail.com
}

\begin{abstract}
Abstrak
Artikel ini membahas tentang pendidikan spiritual santri lansia di Pondok Sepuh Payaman Magelang. Secara kultural, pendidikan telah dimulai dari lahir hingga meninggal dunia. Usaha sadar akan sebuah pendidikan tidak hanya pada usia dini tetapi sampai pada usia lanjut. Perhatian tersebut ada karena perlunya pegangan lansia akan kebutuhan agama sebagai bekal di akhirat. Metode dalam penelitian ini menggunakan kualitatif studi kasus. Pengumpulan data menggunakan wawancara dan pengamatan. Temuan dalam penelitian menunjukkan bahwa motivasi lansia menjadi santri di pondok sepuh karena keinginan mereka sendiri dan keinginan dari keluarga untuk belajar ilmu agama dan meninggal dalam keadaan husnul khotimah. Kehidupan santri lansia selama di pondok, dihabiskan untuk beribadah secara ritual maupun sosial selama lebih dari 12 jam. Tujuan, metode, dan materi pembelajaran menjadi komponen utama dalam pelaksanaan pendidikan spiritual di pondok sepuh. Tidak ada hukuman dalam membina santri lansia. Namun, sangsi sosial berlaku bagi santri lansia yang tidak mengikuti pembelajaran.
\end{abstract}

Kata kunci: Pendidikan, lansia, pesantren

\begin{abstract}
This article discusses the spiritual education of elderly students in Pondok Sepuh Payaman Magelang. Culturally, education has started from birth to death. A conscious effort to an education is not only at an early age but until old age. The attention is there because of the need for the elderly's need for religion as a provision in the afterlife. The method in this study uses qualitative case studies. Data collection used interviews and observations. The findings in the study indicate that the motivation of the elderly to become santri in the pondok senuh is due to their own desires and the desire of the family to study religion and die with husnul khotimah. The life of the elderly student while in the hut was spent on ritual and social worship for approximately 12 hours. The purpose, methods, and learning materials are the main components in the implementation of spiritual education in the pondok sepuh. There is no punishment in fostering elderly students. However, social sanctions apply to elderly students who do not take part in learning.
\end{abstract}

Key words: education, elderly, boarding school 


\section{PENDAHULUAN}

Menurut UU No. 20 Tahun 2003 tentang Sistem Pendidikan Nasional, pendidikan adalah usaha sadar dan terencana untuk mewujudkan suasana belajar dan proses pembelajaran agar peserta didik secara aktif mampu mengembangkan potensi dirinya untuk memiliki kekuatan spiritual, keagamaan, pengendalian diri, kepribadian, kecerdasan, akhlak mulia, serta ketrampilan yang diperlukan bagi bangsa dan negara. Sedangkan menurut Ki Hajar Dewantoro mengartikan pendidikan sebagai sebuah usaha untuk menyokong kemajuan hidup, dalam arti memperbaiki pertumbuhannya baik kesehatan rohani maupun jasmani (Toenlioe, 2016: 8).

Sejalan dengan perkembangan peradaban manusia, perkembangan pendidikan juga semakin menunjukkan kemajuannya secara terus menerus. Bahkan pendidikan berlangsung secara terus menerus dalam kehidupan manusia. Itu, menunjukkan bahwa pendidikan bukan hanya diperuntukkan bagi mereka yang berusia muda saja, namun juga bagi warga yang telah berusia lanjut. Dalam agama Islam, memandang bahwa pendidikan telah dimulai sejak manusia lahir dan berakhir pada waktu ia meninggal dunia (Daulay, 2014: 75). Konsep pendidikan seperti ini dapat dikatakan sebagai pendidikan sepanjang hayat (long life education). Pendidikan sepanjang hajat pada hakikatnya dilakukan untuk memenuhi kebutuhan belajar yang berkembang secara berkelanjutan dalam sejarah kehidupan manusia (Kartakusumah, 2006: 64). Dalam pendidikan sepanjang hayat, dipahami bahwa tidak ada kata terlambat dalam proses belajar, bahkan bagi warga lansia sekalipun. Ini karena, pendidikan sepanjang hayat diyakini sebagai proses belajar yang berlangsung seumur hidup.

Berbicara mengenai pendidikan usia lanjut, masa tua merupakan tahap akhir dalam daur kehidupan manusia (Sunaryo, dkk, 2015: 56). Di usia tua inilah, seseorang dikatakan berada dalam puncak keemasaan, ini karena tidak semua orang mampu untuk mencapai tahap akhir dalam perkembangan kehidupan manusia. Sedangkan lanjut usia sendiri dipahami sebagai seseorang yang telah mencapai usia 60 tahun ke atas (Kementerian Kesehatan, 2017). 
Menurut Sunaryo, dkk (2015: 10) di usia 60 tahun ke atas ini, lansia kerap mengalami penurunan fungsi baik fisik, sosial, dan mental. Akibatnya, tidak sedikit yang menimbulkan berbagai permasalahan. Permasalahan yang cukup krusial selain penurunan fungsi fisik dan sosial adalah permasalahan kesehatan mental. Penelitian Parkar (2015) menunjukkan bahwa seiring bertambahnya proporsi lansia, kesehatan mental juga akan mengalami permasalahan yang cukup serius, mulai dari kegelisahan, depresi, hingga bunuh diri. Temuan Max dalam Su Hong, dkk (2018) memperkuat bahwa depresi dan kecemasan turut menyumbang 32 persen tingkat bunuh diri pada lansia.

Menurut Azizah (2011) lansia juga kerap menghadapi masalah mental yang berkaitan dengan kecemasan dalam menghadapi kematian. Kematian menjadi suatu hal yang ditakuti oleh lansia baik karena sakit ataupun tidak (Santosa dan Ismail, 2019: 89). Meiner dalam Naftali, dkk (2017) juga menjelaskan bahwa kesiapan lansia dalam menghadapi kematian dipengaruhi oleh beberapa aspek yaitu psikologis, sosial, fisik, dan spiritual. Aspek spiritual inilah yang harus ditingkatkan bagi kesehatan mental lansia. Apabila berbagai permasalahan kesehatan mental tersebut tidak ditangani secara tepat, maka akan menimbulkan berbagai permasalahan yang cukup serius bagi masyarakat dan negara.

Dalam menangani kesehatan mental lansia, menurut Jalaludin (2011: 177178), dapat diantisipasi melalui agama dengan cara peningkatan resignasi (penyerahan sepenuhnya kepada Tuhan). Proses resignasi dilakukan sebagai terapi mental yang cukup mujarab di usia tua. Bahkan Maslow dalam Sunaryo, dkk (2015: 271) juga menjelaskan bahwa agama menjadi satu-satunya pegangan yang mampu membuat kehidupan lansia menjadi semakin terintegrasi. Spiritual menjadi suatu kebutuhan bagi lansia dalam memperoleh ketenangan batin (Dewi, 2014: 113). Melibatkan agama dalam kehidupan lansia dianggap sebagai tradisi yang penting. Apabila di usia tua penyerahan diri kepada Tuhan tidak tampak, lansia akan mengalami rasa yang tidak berarti dalam kehidupannya (Dewi, 2014: 114). Maka untuk itu, dibutuhkan setidaknya lembaga baik formal maupun non formal yang dapat membantu meningkatkan spiritual lansia. Sebagaimana 
program pemerintah bagi lansia yang tercantum dalam UU No. 13 Tahun 1998 untuk meningkatkan spiritual lansia dengan tujuan kehidupan lansia menjadi semakin sejahtera baik secara batiniah maupun jasmaniah.

Pondok sepuh menjadi salah satu pendidikan non formal yang bergerak dalam pelayanan kesehatan mental lansia terutama yang terkait dengan kebutuhan dalam menghadapi kematian. Berbagai upaya terus dilakukan pondok sepuh dalam memberikan pelayanan dibidang spiritual. Berdasarkan paparan di atas, tulisan dalam kajian ini berfokus pada pendidikan spiritual santri lansia di pondok sepuh Payaman Magelang.

\section{METODE}

Penelitian ini menggunakan metode kualitatif deskriptif dengan pendekatan studi kasus. Pendekatan ini digunakan untuk menjawab pertanyaan yang mengharuskan peneliti memahami fenomena secara mendalam, bahkan mengeksplorasi dan mengelaborasinya (Rahardjo, 2017). Langkah awal yang dilakukan adalah dengan melakukan pengumpulan data berdasarkan literatur, pengamatan, dan wawancara secara mendalam. Kemudian, dilakukan proses analisa data dan interpretasi data. Interpretasi data dilakukan dengan menarasikan hasil temuan menjadi sebuah cerita yang berpola.

Penelitian dilakukan di sebuah pondok sepuh yang berlokasi di Payaman Magelang. Pemilihan informan menggunakan teknik purposive sampling, yang dipahami oleh Sugiyono (2011 : 85) sebagai teknik dalam pengambilan informan yang didasarkan pada tujuan tertentu dan benar-benar memiliki kriteria yang dibutuhkan. Pengumpulan data menggunakan tehnik pengamatan secara langsung mengenai pendidikan agama di pondok sepuh dan wawancara mendalam kepada santri dan kyai di pondok sepuh. Teknik analisa data dilakukan dengan empat langkah. Pertama, pengumpulan data. Kedua, Reduksi data. Ketiga, penyajian dan analisa data. Keempat, penarikan kesimpulan. 


\section{HASIL DAN PEMBAHASAN}

\section{Awal Mula Berdirinya Pondok Sepuh sebagai Ruang Pendidikan Non- Formal}

Berdirinya Pondok Sepuh di Payaman Magelang tidak terlepas dari sosok KH Anwari Siradj atau yang dikenal dengan panggilan Mbah Siradj. Mbah Siradj juga merupakan pendiri Masjid Agung Payaman yang letaknya berada pada satu komplek pondok sepuh. Awal mula berdirinya pondok sepuh ini, diprakarsai oleh pemikiran Mbah Siradj sekitar tahun 1953. Di tahun-tahun tersebut, masyarakat sekitar Payaman masih kental dengan budaya Jawa, bahkan mayoritas penduduknya beragama Kristen. Alasan tersebut yang mendasari Mbah Siradj untuk melakukan dakwah dengan cara mengadakan pengajian keliling Payaman.

Keinginan Mbah Siradj dalam menyebarkan agama Islam direspon secara positif oleh masyarakat sekitar Payaman yang notabennya merupakan usia lanjut. Lambat laun pengajian keliling digantikan dengan pengajian rutin minggunan yang dilaksanakan setiap hari Selasa di Masjid Agung Payaman. Lambat laun banyak lansia yang datang untuk mengikuti pengajian di masjid. Tujuan utama mereka adalah untuk mengharap berkah dari Mbah Siradj, sehingga tidak sedikit dari masyarakat yang tinggal dan tidur di masjid untuk mengikuti pengajian Mbah Siradj. Dengan antusiusme masyarakat lansia untuk belajar agama, membuat Mbah Siradj mendirikan bangunan kecil di sudut masjid yang diberi nama pondok sepuh hingga saat ini.

Di kalangan masyarakat Payaman dan sekitarnya, Mbah Siradj dikenal sebagai figur yang sakti dan cerdik dalam menangani persoalan pada masa penjajahan. Mbah Siradj wafat pada tahun 1959, dan kepemimpinan pondok sepuh digantikan oleh putranya KH. Ghozin hingga tahun 1975. Di tahun 1975 kepemimpinan pondok sepuh digantikan oleh putranya yaitu KH. Syakir Ghozin hingga tahun 2006. Di era kepemimpinan KH. Syakir Ghozin inilah, pondok sepuh banyak mengalami kemajuan seperti adanya penambahan sholat malam, hingga diadakannya pesantren kilat di setiap bulan Ramadhan. Santrinya bukan hanya dari Jawa, melainkan dari Sumatera, Kalimantan, Bali, dan Wilayah Timur 
lainnya. Setelah wafatnya KH. Syakir Ghozin pada tahun 2006, kepengurusan pondok sepuh kini dilakukan secara TIM.

Upaya pondok dalam memberikan pendidikan non-formal pada masyarakat lanjut usia ternyata tidak sia-sia. Terlihat dari banyaknya lansia yang berasal dari berbagai wilayah untuk belajar ilmu agama dan mencari keberkahan dari Mbah Siradj. Setiap bulan selalu ada lansia yang mendaftarkan diri untuk menjadi santri di pondok sepuh. Apalagi di bulan Ramadhan, pondok sepuh penuh oleh ratusan lansia yang datang untuk mengikuti kajian keagamaan. Lansia yang tinggal bahkan mencapai 300 orang yang didominasi lansia perempuan. Tujuan utama mereka adalah untuk memperbaiki diri dan mencari ilmu agama sebagai bekal di akhirat.

\section{Motivasi Santri Lansia ke Pondok Sepuh}

Motivasi dipahami sebagai dorongan mental yang menggerakkan dan mengarahkan perilaku manusia, termasuk perilaku belajar (Dimyati dan Mudjiono, 2009: 80). Sedangkan menurut Sardiman (2011: 75) memahami motivasi sebagai serangkaian usaha tertentu, agar individu mau dan ingin melakukan sesuatu, dan bila ia tidak suka, maka akan berusaha untuk meniadakan atau menggelakkan perasaan tidak suka tersebut. Lebih lanjut Sardiman menyatakan bahwa motivasi seseorang dapat di rangsang dari luar, akan tetapi motivasi itu tumbuh dari dalam diri seseorang. Di pondok sepuh, motivasi lansia menjadi santri didasarkan pada dua hal yaitu motivasi internal dan motivasi eksternal. Dimyati dan Mudjiono (2009: 91) menjelaskan motivasi internal merupakan motivasi yang bersumber dari dalam diri individu, sedangkan motivasi eksternal dipahami sebagai motivasi yang bersumber dari luar individu.

Motivasi internal lansia datang ke pondok sepuh diantaranya; 1) tidak bisa membaca al-Qur'an, 2) kurang pemahaman ilmu agama, 3) di rumah hanya merawat cucu, 4) ngalap berkah Romo Agung (Kyai Siradj), dan 5) keinginan meninggal dengan husnul khotimah. Sedangkan motivasi eksternal santri datang ke pondok sepuh didorong oleh keluarga baik suami maupun anak. Baik motivasi internal dan eksternal memiliki tujuan yang sama yaitu untuk belajar ilmu agama 
agar meninggal dalam keadaaan husnul khotimah. Sebagaimana penelitian yang dilakukan oleh Kholilurohmah (2019) bahwa motivasi lansia dalam beribadah datang dari dalam diri mereka sendiri yaitu berupa motivasi untuk mengingat akhirat. Temuan penelitian Pajri, dkk (2016) turut menegaskan bahwa motivasi santri melanjutkan pendidikan ke pesantren diantaranya didorong oleh motivasi dari diri sendiri untuk membersihkan diri dari dosa dan memperoleh keridhoan Allah. Sementara itu motivasi yang lain datang dari keluarga santri yang menginginkan anaknya untuk memperoleh kebaikan dunia dan akhirat.

Kematian masih menjadi suatu kecemasan pada lansia, sehingga penyelenggaraan pendidikan spiritual dibutuhkan bagi lansia, agar lansia memiliki ketenangan batin dalam menjemput kematiannya. Sebagaimana Dewi (2014: 113114) yang menyatakan bahwa penguatan agama menjadi tradisi yang penting dilakukan oleh lansia untuk memperoleh ketenangan batin. Tradisi resignasi (penyerahan diri sepenuhnya kepada Tuhan) dilakukan santri lansia pondok sepuh untuk mencapai ketenangan batin, sehingga dapat meninggal dalam keadaan husnul khotimah. Meninggal secara husnul khotimah dan berkumpul dengan para ahli agama di akhirat, menjadi cita-cita tertinggi santri lansia pondok sepuh.

Berdasarkan uraian di atas, dapat disimpulkan bahwa motivasi santri lansia datang ke pondok sepuh tidak lain untuk belajar ilmu agama dan mendekatkan diri kepada Sang Pencipta agar memperoleh ketenangan batin dan meninggal dalam keadaan husnul khotimah.

\section{Kehidupan Santri Lansia Pondok Sepuh}

Aktivitas santri lansia yang tinggal di pondok sepuh cukup beraneka ragam. Mereka terdiri dari berbagai suku, bahasa, dan budaya yang berbeda. Meski terdapat perbedaan suku, budaya dan bahasa, namun hal itu tidak menjadi persoalan bagi santri dalam menuntut ilmu di pondok sepuh. Pola kehidupan santri lansia di pondok sepuh tetap dilandasi dengan sifat kekeluargaan. Kehidupan gotong royong menjadi ciri khas santri lansia di pondok sepuh. Tindakan tersebut, sebagaimana yang dianjurkan dan dilakukan oleh sang guru kepada muridnya. 
Aktivitas untuk memperoleh pendidikan spiritual dilakukan lebih dari 12 jam. Akan tetapi, aktivitas pondok sepuh dalam memberikan pendidikan spiritual kepada santri dilakukan selama 24 jam. Santri lansia berhak memilih dan menentukan sendiri, kajian keagamaan apa yang ingin mereka ikuti. Hal ini karena tidak ada aturan yang mengikat santri lansia untuk mengikuti seluruh aturan main yang ada di pondok sepuh. Meskipun tidak ada sangsi yang mengikat santri secara langsung, akan tetapi sangsi sosial dari santri lainnya akan mereka dapatkan ketika mereka tidak mengikuti kegiatan keagamaan secara terus menerus. Secara kultur, kegiatan keagamaan yang diikuti santri lansia dapat di kategorikan ke dalam istilah islam ritual dan islam sosial.

Islam ritual dipahami sebagai kegiatan keagamaan yang dilandaskan pada hubungan manusia dengan Tuhannya secara langsung atau hablum minAllah. Pendidikan spiritual di pondok sepuh yang termasuk ke dalam islam ritual yaitu bimbingan ibadah wajib dan sunnah, bimbingan membaca Iqro sampai al-Qur'an, bimbingan membaca kitab Ibris (kitab dalam bahasa Jawa: dikhususkan bagi santri yang sudah tamat al-Qur'an), bimbingan puasa, bimbingan zakat, bimbingan haji bagi yang mampu, bimbingan simakan al-Qur'an, dan pengajian rutin setiap hari. Sementara itu, islam sosial dipahami sebagai ibadah yang dilandaskan pada hubungan manusia dengan sesama serta alam semesta atau hablum minannas. Pendidikan yang termasuk ke dalam islam sosial diantaranya ajaran tolong menolong pada sesama, ajaran berbagi pada sesama, ajaran menengok dan mendoakan orang sakit, ajaran bertakziyah.

Aktivitas islam ritual dan islam sosial terus dilakukan santri lansia dalam kesehariannya selama lebih dari 12 jam. Jika diruntut, aktivitas santri telah dimulai sejak pukul 01.00 dini hari. Pada pukul 01.00 dini hari, santri melaksanakan shalat sunnah dan ritual ibadah lainnya seperti membaca al-Qur'an ataupun sekedar berdzikir. Ritual keagamaan tersebut terus mereka lakukan dengan tidak meninggalkan ibadah sosial mereka. Interaksi diantara sesama penghuni pondok, turut menjadi kunci utama dalam keberlangsungan dan eksistensi santri di pondok sepuh. Untuk mencukupi kebutuhan fisik mereka, mayoritas santri memilih untuk memasak sendiri. Bahkan untuk beberapa 
aktivitas lainnya seperti mencuci, bersih-bersih bilik pondok dilakukan secara mandiri. Kegiatan islam ritual dan islam sosial yang dilakukan santri, baru berakhir pada pukul 08.00 malam, bahkan bila ada doa bersama akan berakhir pada pukul 09.00 malam.

Melalui kegiatan islam ritual dan islam sosial, menurut teori pelepasan sosial bahwa lansia yang menjadi santri di pondok sepuh dapat dikategorikan ke dalam lansia yang sukses dalam meninggalkan aktivitas terdahulunya dan memilih untuk memperbaiki diri sebagai bekal di akhirat. Sebagaimana Erikson dalam Rani dan Usha (2018) yang menjelaskan bahwa tidak perlu bagi para lansia untuk mempertahankan aktivitas yang sama dengan yang mereka miliki dahulu, hanya untuk mendapatkan harga diri dan kepuasan hidup yang lebih tinggi di usia tua. Mereka hanya perlu memilih di mana prioritas mereka mampu melepaskan diri dari hubungan yang tidak perlu, untuk fokus pada pandangan yang lebih transenden (pandangan terhadap Tuhan). Baharuddin (2009: 100) turut mengemukakan bahwa masa tua adalah masa yang harus disadari bahwa hidup sudah tidak lagi muda, sehingga harus melakukan perbaikan diri atau refleksi atas diri di masa lalu dan senantiasa mau mendekatkan diri kepada Sang Penciptanya.

Aktivitas islam ritual dan sosial yang terjalin di pondok sepuh, ternyata juga membawa pada keberfungsian lansia kembali di masyarakat. Lansia menjadi tidak kehilangan peran dan dapat tetap eksis di masyarakat. Seperti halnya yang dipaparkan oleh teori aktivitas, bahwa lansia yang berupaya untuk tetap aktif secara fisik, dan sosial akan lebih mungkin mencapai citra diri, integrasi sosial, dan kepuasaan dalam hidupnya (Hillier, dkk, 2010).

Dalam kehidupan sosial, santri lansia di pondok sepuh juga tidak terlepas dari berbagai masalah dalam mengikuti pendidikan spiritual. Masalah yang dialami santri lansia dapat dikategorikan menjadi dua yaitu masalah fisik dan masalah psikologis. Pertama, masalah fisik yang dapat diakibatkan oleh proses penuaan yang terjadi pada lansia. Sebagaimana Pandji (2012: 21) yang menyatakan bahwa lansia merupakan subjek yang rentan terhadap infeksi, karena itu sangat mudah untuk sakit. Di pondok sepuh, sakit menjadi permasalahan sendiri bagi lansia, hal ini juga didasari pada semakin menurunnya fungsi fisik 
lansia. Seperti yang diungkapkan oleh Sunaryo, dkk (2015: 10) bahwa lansia semakin bertambah tua akan semakin kehilangan fungsi baik fisik, mental, dan sosialnya. Tidak sedikit santri yang mengalami sakit, akan tetapi hal tersebut tidak mengurangi semangat santri untuk tetap beribadah. Ketika mereka tidak terlalu sakit, santri lebih memilih untuk tetap tinggal di pondok dan istirahat sejenak. Sementara itu, apabila sakitnya cukup parah, santri biasanya akan meminta keluarga untuk menjemputnya. Baru setelah sembuh, santri akan kembali mengikuti pendidikan spiritual di pondok sepuh.

Kedua, masalah psikologis yang diakibatkan oleh penurunan fungsi mental lansia. Masalah psikologis yang terjadi pada santri lansia di pondok sepuh diantaranya, rasa cemas dan takut saat menghadap sang guru dan ketika bertikai dengan sesama santri. Perasaan cemas dan takut pada diri santri saat menghadap nyai, disebabkan oleh perbedaan tingkat pemahaman agama yang lebih tinggi nyai dibandingkan dengan santri. Bahkan ketakutan tersebut terlihat dalam perilaku santri, yang tidak mau mengikuti pembelajaran atau sekedar grogi saat mengikuti pembelajaran. Untuk memotivasi santri agar mau mengikuti proses pendidikan spiritual, biasanya nyai mendekati santri dan memberikan nasihat. Karena, perbedaan itulah menimbulkan rasa segan, cemas dan takut pada diri santri.

Pertikaian antar sesama santri biasanya terjadi mana kala ada perbedaan pendapat atau miskomunikasi diantara santri lansia. Dampaknya bagi santri yang tidak memiliki daya tahan kuat akan memilih untuk meninggalkan pondok. Hal tersebut, kerap terjadi pada santri baru. Apalagi mereka tinggal dalam satu kamar yang berukuran sekitar $2 \times 2$ meter dan ditempati oleh 2 sampai 3 orang santri. Perbedaan pola hidup dan kebiasaan mereka di masa muda terkadang malah menimbulkan konflik.

\section{Dukungan Sosial Keluarga Santri Lansia di Pondok Sepuh}

Baron dan Byrne (2005: 244) memahami dukungan sosial sebagai pemberian perasaan nyaman baik secara fisik maupun psikologis yang diberikan oleh teman maupun keluarga kepada seseorang untuk menghadapi masalah. Atau dapat dikatakan bahwa dukungan sosial merupakan upaya yang dilakukan untuk melindungi seseorang agar lebih aman. 
Di pondok sepuh, dukungan sosial keluarga merupakan dukungan yang paling effektif bagi santri lansia dalam mengikuti pendidikan spiritual. Dukungan sosial yang diberikan keluarga kepada santri lansia di pondok sepuh dapat dibedakan menjadi dua yaitu dukungan secara material dan non material.

Dukungan secara material dibedakan menjadi uang, pangan, dan sandang. Uang menjadi sumber dukungan yang paling utama bagi santri lansia. Pasalnya, dalam segala aktivitas yang dilakukan membutuhkan uang untuk kelangsungan hidupnya seperti, infak, shodaqoh, membayar air dan listrik, makan, dan lain sebagainya. Meskipun beberapa santri ada yang memperoleh dana pensiun, namun anak maupun menantu tetap menjadi sumber pendapatan yang utama bagi santri di sana. Temuan tersebut mendukung penelitian yang dilakukan oleh WHO dalam Junaidi (2015) yang mengemukakan bahwa hampir seluruh negara yang ada di Asia, bantuan utama material lansia berasal dari keluarga. Walaupun lansia memiliki dana pensiunan, namun pendapatan terbesar adalah dari keluarganya. Lebih lanjut Evandrou, dkk (1986) dalam Junaidi (2015) juga menjelaskan bahwa anak laki-laki maupun anak perempuan merupakan sumber pendapatan yang utama bagi lansia.

Sedangkan dukungan secara non-material dibedakan menjadi pemberian rasa kasih sayang, informasi yang dibutuhkan, dan bimbingan atau arahan. Dukungan sosial non-material tetap diperoleh santri selama kunjungan pihak keluarga. Akan tetapi, tidak semua santri mendapatkan kunjungan dari keluarga. Beberapa santri mengaku, bahwa untuk mengobati rasa rindu kepada anak-anak mereka, biasanya dilakukan dengan menelpon atau video call. Jika keluarga tidak bisa berkunjung, biasanya pihak keluarga akan mentransfer uang untuk mencukupi kebutuhan sehari-hari santri lansia. Menurut Stuart dan Sundeen dalam Tamhir dan Noorkasiani (2009: 8) menyatakan bahwa dukungan dari keluarga mampu menambah rasa percaya diri bagi lansia dalam menghadapi masalah saat ini ataupun yang akan terjadi dikemudian hari.

\section{Pelaksanaan Pendidikan Spiritual pada Santri Lansia di Pondok Sepuh}

Dalam pelaksanaannya, pendidikan spiritual di pondok sepuh memiliki tujuan, materi, dan metode pembelajaran. 


\section{Tujuan}

Tujuan dari pendidikan spiritual di pondok sepuh adalah memberikan bekal agama sesuai dengan ajaran agama Islam kepada lansia agar memperoleh ketenangan batin. Dari tujuan tersebut memunculkan slogan pondok sepuh yaitu "semangat ngibadah kanggo sangu neng alam barzah (semangat beribadah sebagai bekal kehidupan di alam akhirat)".

2. Materi Pembelajaran

Secara umum materi yang ditawarkan di Pondok Sepuh lebih banyak ditekankan kepada islam ritual. Berikut ini materi pembelajaran di pondok sepuh.

a. Iqro mulai jilid 1 sampai jilid 6 .

Materi Iqro dari jilid 1 sampai dengan jilid 6 merupakan materi dasar bagi santri dalam pengenalan huruf-huruf hijaiyah (huruf arab). Materi ini diberikan kepada santri yang belum mengenal dan belum bisa membaca huruf hijaiyah.

b. Al-Qur'an.

Bimbingan al-Qur'an diberikan setelah santri dinyatakan tuntas dalam membaca iqro.

c. Kitab Ibris (kitab tafsir bahasa Jawa)

Bimbingan kitab Ibris atau tafsir al-Qur'an merupakan materi lanjutan yang ditawarkan kepada santri yang telah selesai atau khatam al-Qur'an. Kitab Ibris ini merupakan kitab yang ditafsirkan ke dalam bahasa Jawa.

d. Materi tata cara ibadah

Materi tentang tata cara sholat yang diberikan kepada santri baik pada kegiatan pengajian maupun pada saat kegiatan mengaji kitab. Bimbingan tata cara sholat ini diberikan kepada santri, agar santri dapat lebih tahu mengenai tata cara sholat yang dianjurkan oleh Rasullullah SAW.

e. Materi tata cara bersuci

Materi ini biasanya diberikan kepada santri lansia yang baru masuk ke pondok sepuh, baik itu tata cara wudhu, tayamum, maupun mandi besar.

f. Materi dzikir (wiridan) 
Materi dzikir (wiridan) diberikan kepada santri secara langsung dalam praktek ibadah sehari-hari. Selain melalui rutinitas harian, dzikir (wiridan) juga dipraktekkan saat kegiatan berjanjen atau maulud ndiba'.

g. Materi akhlaqul kharimah

Materi akhlakul kharimah lebih berisi pada anjuran kepada santri untuk memiliki sikap saling membantu dan mengingatkan dalam kebaikan kepada sesama manusia, yang tercermin dalam kehidupan sehari-hari santri di Pondok Sepuh.

h. Materi al-hadits

Materi al-hadits yang diberikan berupa hadits-hadits Rasul terkait peribadatan dan juga kemanusiaan agar santri dapat konsisten dalam menjalani pendidikan spiritual di pondok sepuh.

Materi tersebut merupakan gambaran umum yang diberikan kepada santri lansia. Akan tetapi, pada kenyataannya materi tidak bersifat baku, namun lebih banyak disesuaikan dengan kondisi dan kebutuhan santri lansia.

3. Metode Pembelajaran

Metode pembelajaran digunakan sebagai penunjang agar materi dapat tersampaikan dengan baik kepada santri lansia. Secara umum metode pembelajaran yang diterapkan pondok sepuh kepada santrinya yaitu:

a. Metode ceramah atau nguping

Metode ceramah atau nguping banyak digunakan kyai saat mengisi pengajian yang dilakukan di masjid agung Payaman Magelang. Metode ceramah ini dinilai cukup efektif mengingat para santri merupakan santri usia lanjut.

b. Metode Demonstrasi

Metode ini dipilih sebagai cara yang efektif dalam memberikan contoh yang benar mengenai tata cara shalat, dan bersuci. Bagaimana seharusnya mengangkat tangan ketika takbiratul ihram, posisi tangan saat bersujud, posisi saat duduk diantara dua sujud, tata urutan dalam berwudhu, dan lain sebagainya.

c. Metode Tanya Jawab 
Metode ini digunakan apabila ada materi yang belum dipahami oleh santri, maka santri boleh bertanya kepada sang guru. Metode ini dilakukan di 15 menit terakhir ketika penjelasan materi.

d. Metode Sorogan

Metode sorogan digunakan pada saat santri lansia melaksanakan kegiatan simakan Qur'an. Metode ini dilakukan secara bergantian selesai shalat ashar hingga menjelang shalat magrib. Selain itu, metode ini juga digunakan pada saat proses mengaji. Santri menyodorkan bacaannya kemudian akan disimak oleh nyai. Setelah selesai nyai akan menjelaskan maksud dari ayat yang dibaca.

e. Metode Bimbingan

Metode bimbingan dilakukan secara terus menerus agar santri lansia terbiasa melakukan kegiatan islam ritual maupun islam sosial. Seperti misalnya, pada santri yang belum lancar dan benar membaca al-Qur'an, maka dilakukan proses bimbingan tersendiri semacam privat sampai dengan santri terbiasa dan lancar membaca al-Qur'an.

f. Metode Berjanjen dan Wiridan

Metode ini termasuk ke dalam metode pembiasaan agar santri terbiasa untuk melakukan dzikir kepada Allah dan bersholawat kepada Rasulullah. Metode ini dipraktikkan secara langsung oleh sang guru bersama santrinya pada waktu selesai shalat, selesai pengajian, dan pada saat doa bersama.

Berdasarkan temuan di atas, dapat disimpulkan bahwa metode yang digunakan dalam pelaksanaan pendidikan spiritual adalah learning by doing. Di mana santri belajar sembari mempraktekkannya dalam kehidupan sehari-hari. Misalnya tata cara shalat, tata cara bersuci, tata cara melafadzkan huruf hijaiyah yang benar, merupakan bentuk pembelajaran yang diberikan oleh kyai maupun nyai yang secara langsung direspon dan dipraktikkan oleh santri lansia. 


\section{Hubungan Santri dengan Penghuni Pondok dalam Pelaksanaan Pendidikan Spiritual}

Aktivitas islam ritual dan islam sosial yang dijalani santri setiap hari tidak hanya menitikberatkan pada ketenangan batin, namun juga menciptakan relasi sosial baru dan kedekatan yang kuat diantara penghuni pondok.

1. Kedekatan santri dengan kyai

Kedekatan diantara santri lansia dan kyai diikat oleh ketakdiman yang cukup kuat. Setiap perintah dan keputusan yang diambil kyai menjadi pegangan para santri lansia di pondok sepuh. Sebagaimana Dhofier (2011 : 55) menerangkan bahwa kyai memegang kekuasaan dan wewenang mutlak dalam kerajaan kecil yang disebut pesantren. Bahkan secara sosiologis Qomar, M (2006: 54) menyatakan bahwa kedudukan seorang kyai dipandang memiliki kemiripan dengan kedudukan seorang raja. Kyai pada dasarnya memiliki, mempertahankan, mengasuh, dan mengembangkan pesantren sehingga mendapat penghormatan yang tinggi di kalangan masyarakat layaknya raja.

Kedudukan yang dimiliki kyai menjadi tradisi turun temurun dikalangan para santri. Tradisi menghormati pada setiap perintah kyai menjadi syarat mutlak yang harus dipatuhi. Menurut Dhofier (2011) mengemukakan bahwa kedekatan santri lansia yang dibingkai dalam ketakdiman berlaku seumur hidup, meski ia tidak lagi mengenyam pendidikan di pesantren atau sang kyai telah meninggal dunia. Begitu pula di pondok sepuh, tradisi menghormati kyai serta tunduk terhadap segala keputusannya menjadi tradisi yang harus dijalankan santri lansia. Meski, secara rentang usia antara kyai dan santri lansia tidak berbeda jauh. Namun, pemahaman ilmu agama yang jauh lebih tinggi-lah yang membuat kyai berada pada strata sosial puncak.

Kedekatan antara santri dan kyai tetap berlanjut mana kala santri lansia sudah meninggal dunia mendahului sang guru. Keluarga santri lansia tetap dianjurkan untuk menjalin silaturahmi kepada para kyai di pondok sepuh. Kedekatan santri dan kyai merupakan sebuah hubungan emosional yang bersifat kontinue (keberlanjutan). Artinya, hubungan tersebut tidak pernah dapat terlepaskan. 
Kedekatan santri di pondok sepuh layaknya orang tua dan anak. Kyai dianggap sebagai orang tua santri yang harus mendidik anaknya agar dapat menjalani kehidupan baik akhirat maupun keduniaan yang didasarkan pada nilai-nilai agama. Sementara itu, santri dianggap sebagai anak dari sang kyai, yang harus tunduk dan patuh pada nasihat orang tuanya. Kedekatan emosional antara kyai dengan santri di pondok sepuh begitu dekat, hingga dalam segala tindakan santri selalu meminta nasihat dari sang guru. Kedekatan tersebut juga tampak, mana kala santri lansia akan pulang ke rumah. Sebelum pulang, santri akan pamit dan menemui sang guru. Sebaliknya, ketika santri lansia tiba di pondok sepuh, mereka akan segera menemui sang guru dan memberikan bingkisan, layaknya anak kepada orang tuanya. Secara garis besar kedekatan santri dengan kyai atau sang guru terikat oleh emosional yang cukup kuat yaitu ketakdiman pada sang guru.

2. Kedekatan santri lansia dengan sesama.

Pendidikan spiritual yang dilaksanakan oleh pondok sepuh turut membawa pada kedekatan santri lansia dengan sesamanya. Kehidupan santri lansia di pondok sepuh menjadi lebih berarti dan bermakna. Mereka mengaku mendapatkan keluarga dan teman baru yang satu tujuan yaitu mencari bekal untuk di akhirat. Kesamaan tujuan, umur, dan cara berbicara membawa santri dalam lingkaran kerukunan yang nyata.

Kedekatan santri lansia dengan sesama terlihat dalam berbagai kehidupan di pondok sepuh. Kedekatan tersebut terjalin dalam berbagai aktivitas santri. Dari bilik kamar sampai pada makanan, santri lansia saling berbagi dan membantu. Menurut santri lansia, dengan berbagi akan membersihkan jiwa mereka dari masa lalu. Bukan hanya sampai disitu, terkadang santri juga kerap meminjamkan uangnya pada santri lain yang belum mendapatkan kiriman dari keluarga atau malah memberikannya. Materi sudah bukan lagi menjadi prioritas santri lansia, akan tetapi prioritas mereka adalah menjadi bermakna bagi orang lain.

Hubungan santri dengan sesama juga sampai pada menjalin silaturahmi hingga ke keluarga masing-masing santri. Mereka saling mengenal satu sama 
lain dan saling membantu dalam berbagai aktivitas. Sehingga, gotong royong menjadi ciri khas di pondok sepuh. Oleh karena itu, kedekatan santri dengan sesama sangat erat karena mereka memiliki tujuan yang sama yaitu mencari bekal setelah kehidupan di dunia dan meninggal dalam keadaan husnul khotimah.

\section{SIMPULAN}

Pondok sepuh merupakan sebuah pesantren khusus lanjut usia yang berada di Payaman Magelang. Tujuan utama pondok sepuh menyelenggarakan pendidikan spiritual adalah semangat beribadah sebagai bekal di akhirat. Masuknya santri lansia di pondok didasari motif internal maupun eksternal. Motivasi internal lebih pada motivasi dari dalam diri mereka sendiri, sedangkan motivasi eksternal diperoleh dari keluarga dan teman. Kehidupan sosial lansia di pondok sepuh diisi dengan mengikuti pendidikan spiritual yang terdiri dari pendidikan islam ritual dan islam sosial. Materi pendidikan spiritual ditekankan pada peribadatan sedangkan metode pembelajaran lebih kepada learning by doing. Kehidupan sosial santri lansia didukung oleh keluarga santri baik berupa dukungan material dan sosial. Harapan dari penyelenggaraan pendidikan spiritual adalah santri lansia dapat lebih dekat dengan Sang Penciptanya dan memiliki sikap jiwa sosial kepada sesama agar keinginan mereka meninggal dalam keadaan husnul khotimah dapat tercapai.

\section{DAFTAR PUSTAKA}

Azizah, L. M. (2011). Keperawatan Lanjut Usia. Yogyakarta: Graha Ilmu.

Baharuddin. (2010). Pendidikan dan Psikologi Perkembangan. Yogyakarta: ArRuzz Media.

Baron, R. A \& Byrne, D. (2005). Psikologi Sosial. Jakarta: Erlangga.

Daulay, H. P. (2014). Pendidikan Islam Dalam Perspektif Filsafat. Jakarta: Kencana.

Dewi, S. R. (2014). Keperawtan Gerontik. Yogyakarta: CV Budi Utama.

Dhofier, Z. (2011). Tradisi Pesantren. Jakarta: LP3ES. 
Dimyati dan Mudjiono. (2009). Belajar dan Pembelajaran. Jakarta: PT. Rineka Cipta.

Hillier, S. M, dkk (2010). Aging the Individual and Society Chapter 4: Theories in Social Gerontology. Diakses di https://www.cengage.com/custom/static_content/OLC/1111067740/dat a/Condensed_AgingIndividandSoc_HillierBarrow_ch04.pdf. Pada 15 Januari 2019.

Jalaluddin. (2011). Psikologi Agama. Jakarta: Grafindo Persada.

Junaidi. (2015). Peranan Keluarga Dalam Pemeliharaan Penduduk Lanjut Usia. Diunduh di http://www.researchgate.net/publication/277130987. pada 15 januari 2019

Kartakusumah, B. (2006). Pimpinan Adiluhung Genealogi Kepemimpinan Kontemporer. Jakarta: Blantika.

Kementerian Kesehatan Republik Indonesia. (2017). Analisis Lansia di Indonesia. Di unduh di http://depkes.go.id/download.php\%3Ffile\%3Ddownload/pusdatin/lain -

lain/Analisis\%2520Lansia\%2520Indonesia\%25202017.pdf $+\& c d=1 \&$ $h l=i d \& c t=c \ln k \& g l=i d$. Pada 9 Agustus 2018.

Kholilurahmah, S. A. (2019). Dukungan Sosial dan Motivasi Dalam Beribadah Pada Lansia di Pondok Lansia Berdikari Tangerang. Skripsi. Tidak diterbitkan. Universitas Islam Negeri Syarif Hidayatullah.

Naftalia, A. R, dkk. (2017). Kesehatan Spiritual dan Kesiapan Lansia dalam Menghadapi Kematian. Buletin Psikologi. Vol.25, No. 2, pp. 124-125.

Pajri, dkk. (2016). Motivasi Santri Melanjutkan Pendidikan ke Pesantren Darussakam Kecamatan Labuhan Haji Kabupaten Aceh Selatan. Jurnal Ilmiah Mahasiswa Pendidikan Kewarganegaraan Unsyiah. Vol.1, No. 1, pp: 120-127.

Pandji, D. (2012). Menembus Dunia Lansia. Jakarta: PT. Elex Media Komputindo.

Parkar, S. (2015). Elderly Mental Health. Journal Mens sana monographs 13 (1): 91-99.

Qomar, M. (2006). Pesantren Dari Transformasi Metodologi Menuju Demokrasi Institusi. Jakarta: Erlangga.

Rani, K \& Usha. (2018). Disorganisation In Social Gerontology. Journal of Gerontology \& Geriatric Research. Vol. 7, No. 2, pp. 466.

Santosa, H \& Ismail, A. (2009). Memahami Krisis Lanjut Usia. Jakarta: Gunung Mulia. 
Sardiman. (2011). Interaksi dan Motivasi Belajar Mengajar. Jakarta: Rajawali Press.

Su, Hong, dkk. (2018). The Mediating Effect of Coping Style on Personality and Mental Health Among Elderly Chinese Emphty-Nester: A cross sectional study. Archives of Gerontology and Geriatrics. Vol. 75, pp. 197-201.

Sugiyono. (2011). Metode Penelitian Kualitatif, Kuantitatif, dan R \& D. Bandung: Alfabeta.

Sunaryo, dkk. (2015). Asuhan Keperawatan Gerontik. Yogyakarta: Andi Offset.

Tamher \& Noorkasiani. (2009). Kesehatan Usia Lanjut Dengan Pendekatan Asuhan Keperawatan. Jakarta: Salemba Medika.

Toenlioem A, JE. (2016). Teori dan Filsafat Pendidikan. Malang: Gunung Samudera.

UU No. 13 Tahun $1998 . \quad$ Diunduh di http://www.bphn.go.id/data/documents/98uu013.pdf. Pada 9 Agustus 2018.

UU No. 20 Tahun 2003. Diunduh di https://kelembagaan.ristekdikti.go.id/wpcontent/uploads/2016/08/UU_no_20_th_2003.pdf. Pada 15 Agustus 2018. 